\title{
HAKSIZ FİİLDEN DOĞAN DAVALARDA ORTAK YETKİLİ MAHKEME SORUNU*
}

\author{
The Problem of the Common Competent Court in Jurisdiction of Tort Cases \\ Dr. Öğr. Üyesi Hakan ALBAYRAK** \\ Arş. Gör. Tahsin MAVZER***
}

\begin{abstract}
ÖZ
Hukuk Muhakemeleri Kanunu'nda (HMK) genel yetkili mahkemeye ilişkin yetki kuralından sonra birtakım özel yetki kuralları düzenlenmiştir. Yetkili mahkemeye ilişkin kurallar açısından önem arz eden husus, davalıların birden fazla olması halinde yetkili mahkemenin nasıl belirleneceğine yöneliktir. HMK'nda, davalıların birden fazla olması ve davalıların tamamı hakkında kanunda dava sebebine göre ortak yetkili mahkemenin belirlenmiş olması halinde o ortak yetkili mahkemenin davaya bakacağı düzenlenmiştir. Bu düzenlemenin doktrinde ifade edildiği gibi kesin yetki kuralı olup olmadığının incelenmesi gerekmektedir. Çünkü bu belirleme; kuralın hukuki niteliğinin tespitini, uygulanmasını ve meydana gelecek sonuçları etkilemektedir. Nitekim konu ile alakalı olarak yargı kararlarında ve doktrinde farklı görüşler yer almaktadır. Bu çerçevede çalışmamızda düzenlemenin hukuki niteliği ele alındıktan sonra konuya ilişkin görüşümüz sunulacaktır.
\end{abstract}

ANAHTAR KELIMELER: Mahkemelerin Yetkisi, Ortak Yetkili Mahkeme, Kamu Düzeni, Haksız Fiilden Doğan Davalarda Yetki, Davalıların Birden Fazla Olması

\section{ABSTRACT}

Several special competents rules were introduced in the Code of Civil Prosedure after the regulation of the general rule for the competent court. The point which is important in terms of rule for the competent court is how to determine in case of more than one of the defendants. If there are more than one defendants and a court which has common jurisdiction related all of defendants in accordance with cause of case, it is regulated that this court would handle the case. It is necessary to examine whether this regulation is an exclusive competence rule as stated. Because the determination of the legal character affects the implementation and results of the rule. Indeed, with regard to the subject it is located different opinions in the doctrine and judicial decisions. In this context, in our study by considering the legal character of the regulation will be given our opinion on the legal character of the regulation in question.

KEY WORDS: Competency of Court, Common Competent Court, Public Order, Jurisdiction of Tort Cases, More Than One of the Defendants.

* Yayın Kuruluna Ulaştığı Tarih: 29.01.2019

Kabul Edildiği Tarih: 22.07.2019

DOI Numarası: $10.15337 /$ suhfd. 519135

** Çukurova Üniversitesi Hukuk Fakültesi Medeni Usul ve İcra iflas Hukuku Anabilim Dalı

E-mail Adresi: hknalbayrak@hotmail.com

ORCID ID: 0000-0001-6097-1296

*** Çukurova Üniversitesi Hukuk Fakültesi Medeni Usul ve İcra Iflas Hukuku Anabilim Dalı

E-mail Adresi: tmavzer@cu.edu.tr

ORCID ID: 0000-0002-5951-5987

Makaleye Atıf: Albayrak, Hakan/ Mavzer, Tahsin: Haksız Fiilden Doğan Davalarda Ortak Yetkili Mahkeme Sorunu, Selçuk Üniversitesi Hukuk Fakültesi Dergisi, C.27, S.2, 2019, s.279-306. 


\section{IÇINDEKILER}

GiRiş... 281

I. ORTAK YETKILI MAHKEME. 281

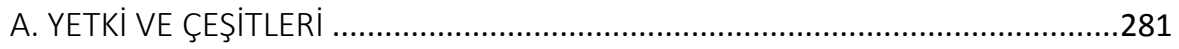

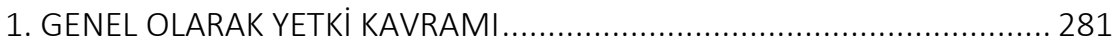

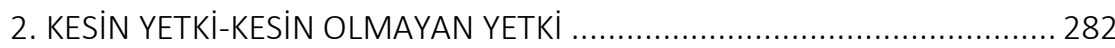

3. YETKI KURALLARINDA KAMU DÜZENI KAVRAMI ................................ 284

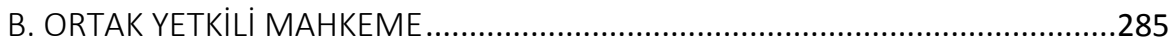

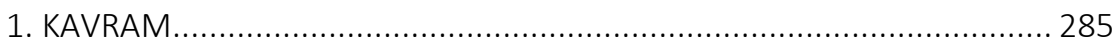

2. ORTAK YETKILI MAHKEMEYE ILIŞKIN DOKTRINDEKI GÖRÜŞLER ............ 286

3. ORTAK YETKILI MAHKEMEYE ILIŞKIN YARGI KARARLARI....................... 289

II. HAKSIZ FIILDEN DOĞAN DAVALARDA ORTAK YETKILI MAHKEME........................ 291

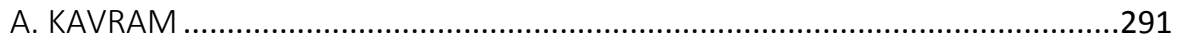

B. HAKSIZ FiILDEN DOĞAN DAVALARDA ORTAK YETKILI MAHKEMEYE ILIŞKIN

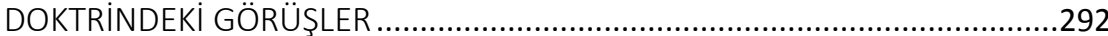

C. HAKSIZ FIILDEN DOĞAN DAVALARDA ORTAK YETKILI MAHKEME ILE ILGILI

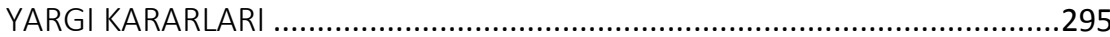

III. HAKSIZ FIILDEN DOĞAN DAVALARDA ORTAK YETKILI MAHKEMEYE ILIŞKIN DEĞERLENDIRMEMIZ 297

SONUÇ. 302

KAYNAKLAR 304 


\section{Giriş}

Hukuk Usulü Muhakemeleri Kanunu'nda (HUMK) olduğu gibi Hukuk Muhakemeleri Kanunu'nda da ortak yetkili mahkemeye ilişkin yetki kuralına yer vermiştir. HMK'nun 7. maddesinin birinci fıkrasında "Davalı birden fazla ise dava, bunlardan birinin yerleşim yeri mahkemesinde açılabilir. Ancak, dava sebebine göre kanunda, davalıların tamamı hakkında ortak yetkiyi taşıyan bir mahkeme belirtilmişse, davaya o yer mahkemesinde bakılır" şeklinde yer alan düzenleme, davalıların birden fazla olması halindeki yetki kurallarını düzenlemektedir. Söz konusu düzenlemenin ikinci cümlesi ise ortak yetkili mahkemeye ilişkindir.

Ortak yetkili mahkemeye ilişkin düzenlemenin doktrinde kimi yazarlarca kesin yetki kuralı olduğu ileri sürülmektedir. Doktrinde kesin yetki kuralı olduğu ileri sürülen bu düzenlemenin çoğunlukla haksız fiilden doğan davalara uygulanacağı ifade edilmektedir. Ancak yargı kararlarında söz konusu düzenleme kesin yetki kuralı olarak kabul edilmemekte ve bu düzenlemenin seçimlik yetki kurallarını bertaraf etmeyeceği kabul görmektedir. Yargı kararları söz konusu düzenlemeyi haksız fiilden doğan davalarda, iş mahkemesinin görevli olduğu davalarda ve tüketici mahkemesinin görevli olduğu davalarda ele almaktadır. Bu davalar bakımından söz konusu düzenlemenin kesin yetki kuralı olduğu şeklinde bir değerlendirme yapılmamaktadır. Dolayısıyla ortak yetkili mahkemeye ilişkin düzenlemenin hukuki niteliğini ele alma ve devamında haksız fiilden doğan davalar bakımından bir değerlendirme yapma ihtiyacı doğmaktadır.

Bu çerçevede çalışmamızda, ortak yetkili mahkeme kavramına yetki kavramı açısından bakılacak olup doktrindeki görüşlere ve yargı kararlarına yer verilecektir. Sonrasında ise haksız fiilden doğan davalar açısından doktrindeki görüşlere ve yargı kararlarına yer verilecek olup son olarak konuya ilişkin değerlendirmemizi ele almaya çalışacağız.

\section{ORTAK YETKILI MAHKEME}

\section{A. YETKI VE ÇEŞITLERI}

\section{GENEL OLARAK YETKI KAVRAMI}

Kişiler hukuki korunmanın sağlanmasını ya da yargısal denetimi sağlamaya yönelik taleplerini bir hukuk devletinde yargı organlarına yöneltir. Anayasa'nın 9. maddesinde yargı işlevinin bağımsız ve tarafsız mahkemelerce yerine getirileceği düzenlenmektedir. Bu çerçevede yargı işlevi, bağımsız ve tarafsız yargı organlarınca yargısal 
usullere uyularak objektif hukukun somut olay veya ilişkiye uygulanması olarak tanımlanabilir ${ }^{1}$.

Yargı işlevini yerine getirecek mahkemelerin, önlerine gelen birtakım uyuşmazIıkları veya işleri, nitelik ve yer bakımından inceleyebilme iktidarına "geniş anlamda yetki" denilmektedir². Geniş anlamda yetki kavramına; "görev" (madde itibariyle yetki) ve "yetki" (yer itibariyle yetki) kavramları dâhildir³. Görev, bir mahkemenin incelebileceği uyuşmazlıkların veya işlerin nitelikleri esas alınarak kanunla tayin edilmesinin bir sonucudur. Ancak bir mahkemenin uyuşmazlığın veya işin niteliğinden ötürü bir davada görevli olması aynı nitelikte ülkenin her yerinden gelmesi muhtemel davalarda da yetkili mahkeme olduğu anlamına gelmemektedir. Bu bağlamda bir mahkemenin yargılama yetkisinin coğrafi alanla ifade edilmesi "yargı çevresi "ni işaret etmektedir ${ }^{4}$ Mahkemenin görevli olduğu uyuşmazlık veya işler bakımından yer olarak bakabilme iktidarına ise "dar anlamda yetki" denilmektedir". Bir başka ifade ile mahkemelerin yetkisi, bir uyuşmazlığa veya işe neredeki mahkemenin bakacağı sorusuna cevap vermektedir. Mahkemelerin yetkisi; göreve ilişkin kurallardaki gibi kanunla düzenlenir ve aksi belirtilmedikçe yetkiye ilişkin kurallar HMK hükümlerine tabidir.

\section{KESIN YETKI-KESIN OLMAYAN YETKI}

Yetkili mahkemenin belirlenmesinde ana kural HMK'nun 6. maddesinin birinci fıkrasında düzenlendiği üzere “...davalı gerçek veya tüzel kişinin davanın açıldığı tarihteki yerleşim yeri mahkemesidir." Davalının yerleşim yeri esasına göre tayin edilecek mahkemeye "genel yetkili mahkeme" denilmektedir". Mahkemelerin yetkisine ilişkin genel kurala ilaveten ya da o kuraldan ayrı olarak uyuşmazlık veya işlerin özellikleri gereği ayrıca bir yetki kuralı öngörülmesi mümkündür. Genel yetki kuralının yanı sıra düzenlenen yetki kurallarına "özel yetki kuralı" denilmektedir. Özel yetki kurallarının niteliği de ilgili düzenlemeye göre "kesin olmayan yetki kuralı" veya "kesin yetki

1 ARSLAN/YILMAZ/TAŞPINAR AYVAZ/HANAĞASI, s. 66; ARSLAN/TANRIVER, s. 35; TANRIVER, Usul, s. 74; AKKAN, Pekcanıtez Usul, s. 79; AKKAN, Etkin Hukuki Koruma, s. 44; KURU, Usul, s. 45.

2 KARADEMIR AYDEMIR, s. 35; POSTACIOĞLU, s. 148; BILGE/ÖNEN, s. 178

3 KURU, Muhakeme, s. 161; BILGE/ÖNEN, s. 178; POSTACIOĞLU, s. 148.

4 TANRIVER, Usul, s. 99; ARSLAN/YILMAZ/TAŞPINAR AYVAZ/HANAĞASI, s. 206; KARSLI, s. 263; KURU, Usul, s. 104; ÜSTÜNDAĞ, s. 194.

5 AKKAN, Pekcanıtez Usul, s. 267; ALANGOYA/YILDIRIM/DEREN YILDIRIM, s. 83; BILGE/ÖNEN, s. 178; POSTACIOĞLU, s. 148.

6 POSTACIOĞLU/ALTAY, s. 112; BILGE/ÖNEN, s. 179. 
kuralı" şeklinde olabilmektedir7? Bir yetki kuralının lafzından o kuralın açıkça, tartışmasız, kesin ve emredici biçimde düzenlendiği anlaşımadığı takdirde o yetki kuralı kesin olmayan yetki kuralı niteliği taşıyacaktır ${ }^{8}$. Kesin olmayan yetki kuralının bulunduğu durumlarda davacının yetkili mahkeme açısından davasını açıı̆ı esnada kullanabildiği bir seçim hakkı söz konusu olmaktadır.

Yetkiyi belirleyen kanun hükmü, bir uyuşmazlığın veya işin, bir mahkeme tarafından karara bağlanabileceğini düzenleyip belirtilen mahkemenin dışında başka bir mahkeme tarafından karara bağlanmasını engellemiş ise kesin yetki kuralı söz konusu olur ${ }^{9}$. Doktrinde bir görüşe göre yetkili mahkemenin birden fazla tayin edilmesi durumunda da o yetki kuralı, nitelik itibariyle kesin yetki kuralı olabilecektir ${ }^{10}$. Bizim de katıldığımız diğer bir görüşe göre ise; kesin yetkili mahkeme niteliği sadece bir mahkemenin yetkili olduğu durumda söz konusu olabilir ve yetkili mahkeme birden fazla tayin edilmişse bu düzenleme nitelik itibariyle kesin yetki kuralı niteliğinde olamaz ${ }^{11}$. Bu durumun aksi ancak kanun koyucunun açık bir iradesiyle mümkündür.

Genel yetkili mahkemenin yetkisi kesin olmayan yetki kuralı niteliğinde düzenlenmiştir ${ }^{12}$. Genel yetki kuralının yanı sıra belirli hukuki ilişkilerin gereği olarak birtakım özel yetki kuralları da düzenlenmiştir ${ }^{13}$. Kesin yetki istisnai nitelikte olup kanunun düzenlemesinden açıkça anlaşıldığı takdirde söz konusu olmaktadır ${ }^{14}$. Kanunun açıkça kesin yetki olarak nitelemediği hallerde düzenlenen yetki kuralının kesin yetki kuralı niteliği bulunamaz. Açıkça bu şekilde bir belirleme yapılmadığı takdirde yetki kuralı

7 BILGE/ÖNEN, s. 179.

8 TANRIVER, Usul, s. 245, 247; KURU, Usul, s. 104; TOPUZ, s. 164.

9 KARADEMIR AYDEMIR, s. 99; TANRIVER, Usul, s. 244; YILMAZ E. , s. 281; KURU, Usul, s. 105; ARSLAN/YILMAZ/TAŞPINAR AYVAZ/HANAĞASI, s. 206.

10 TANRIVER, Usul, s. 244; AKKAN, Pekcanitez Usul, s. 293; AKKAYA, s. 272-273.

11 Yargıtay'a göre, kesin yetki kuralııın varlığı, kanunda tek mahkemenin yetkili olarak gösterilmesiyle mümkündür. "Davacı vekilinin 08.10.2015 tarihli dilekçesi davayı takip iradesini içermektedir. Ancak boşanma ve ayrılık davaları yetkinin kesin olmadığı davalardır. Kesin yetkinin olmadığı davalarda yetki itirazı cevap dilekçesi ile ilk itiraz olarak ileri sürülebilir. (HMK m. 116/1-1)" (Y. 2. HD, T. 12.05.2016, E. 2016/6798 K. 2016/9873; aynı yönde bkz. Y. 2 HD, T. 17.02.2016, E. 2015/12532 K. 2016/2764: Naklen AKKAYA, s. 272-273).

12 KONURALP, s. 214. Doktrinde bu kural, kesin olmayan ve kamu düzeninden sayılmayan yetki kuralı olarak bahsedilmiştir AKKAN, Pekcanıtez Usul, s. 269-270; ARSLAN/YILMAZ/TAŞPINAR AYVAZ/HANAĞASI, s. 211; KURU, Muhakeme, s. 382; KURU, Usul, s. 105; ancak kesin yetki kavramıyla birlikte kamu düzeni açısından yapılan değerlendirmelerin öneminin azalmış olduğu düşüncesindeyiz.

13 AKKAN, Pekcanitez Usul, s. 267; KURU, Muhakeme, s. 382.

14 TANRIVER, Usul, s. 235, 247; ARSLAN/YILMAZ/TAŞPINAR AYVAZ/HANAĞASI, s. 206-211; AKIL, s. 108; YILMAZ E. , s. 281; GÖRGÜN, s. 89; KURU, Muhakeme, s. 432. 
düzenlemelerinin kesin olmayan yetki kuralı niteliğinde olduğunun kabulü ile bu yetki kuralları hakkında kural olarak tarafların serbestçe tasarruf edilebileceğinin anlaşıması gerekir ${ }^{15}$.

\section{YETKI KURALLARINDA KAMU DÜZENI KAVRAMI}

"Kamu düzeni" kavramının hukuktaki yerinin tayini ve sınırlarının tespiti oldukça zor olmakla birlikte ${ }^{16}$ bir kuralın kamu düzeniyle ilişkisini tayin edebilmenin yolu o kuralın işlevini, amacını ve etkilerini değerlendirmekten geçmektedir ${ }^{17}$. Kamu düzeni medeni yargıda toplumsal barış, hakkaniyet, usul ekonomisi gibi nedenlerden ötürü kabul edilmektedir ${ }^{18}$.

Kamu düzeni kavramı; HUMK döneminde yetki sözleşmesinin yapılabilmesinin mümkün olup olmadığının belirlenmesi açısından önem arz eden bir kavramdı ${ }^{19}$. Çünkü yetki sözleşmesine ilişkin HMK'nun 17. ve 18. maddelerinde bulunan sınırlamalar HUMK döneminde mevcut değildi. Bu nedenle yetki sözleşmesinin konusuna giren uyuşmazlıkları belirleyebilmek için bir dava üzerinde tarafların serbeste tasarruf edip edemeyeceklerinin ve bundan daha geniş bir anlam taşıyan davanın kamu düzenine ilişkin olup olmadığının önemi oldukça fazlaydı. Bu çerçevede yargı kararları ve doktrin tarafından bu kavramların sınırı çizilmeye çalışımıştı ${ }^{20}$.

Ancak HMK ile birlikte yetki sözleşmesinin şartlarının özel olarak düzenlenmesi ve yetki sözleşmesinin kapsamının daraltılması nedeniyle yetki konusunda yapılan ayrımları kamu düzeni kavramı ile açıklamaya çalışmanın anlamının azaldığı kanaatindeyiz. Çünkü HMK ile birlikte yetki sözleşmesinin yapılabilmesi için artık HMK'nun 17. ve

15 YILMAZ E. , s. 275; POSTACIOĞLU, s. 153.

16 Doktrinde bir görüşe göre kamu düzeni; toplumun huzurunu ve güvenliğini, esenliğini ve sağlığını korumaya yönelik kurallar şeklinde tanımlanmaktadır (GiRiTLi/BiLGEN/AKGÜNER/BERK, s. 1156); diğer bir görüşe göre ise kamu düzeni; bir toplumun belirli bir zaman dilimi içerisinde siyasi, sosyal, ekonomik, ahlaki ve hukuki açılardan temel yapısını belirleyen ve temel çıkarlarını koruyan kurum ve kurallar bütününü ifade eder (TANRIVER, Kamu Düzeni, s. 476); doktrinde özel hukukta kamu düzeninin; toplumun menfaatlerini koruma amacıyla emredici nitelik taşıyan hukuk kuralı olduğu ileri sürülmektedir (OĞUZMAN/ÖZ, s. 83; AKIL, s. 109); özel hukukta kamu düzeni kavramı ile ilgili olarak ayrıntılı bilgi için bkz. (KOCAYUSUFPAŞAOĞLU/HATEMI/SEROZAN/ARPACI, s. 546-549).

17 DAYINLARLI, S. 6.

18 YILMAZ M. , s. 5.

19 BOLAYIR, Yetki Sözleşmeleri, s. 180; AŞIK, s. 13.

20 Doktrinde genel kabul gören, kamu düzenine ilişkin ancak kesin olmayan yetki kuralları; boşanma ve ayrılık davalarındaki mahkemelerin yetkisi (TMK m. 168) ve boşanma sonrası nafaka davalarının açılacağı mahkemelerin yetkisi (TMK m. 177) olarak örneklendirilebilir. Ayrıca bu ayrım açısından değerlendirmeler için bkz. (YILMAZ E. , s. 281; KURU, Usul, s. 105). 
18. maddelerinde bulunan şartların sağlanması gerekir. Buna göre yetki sözleşmesinin yapılabilmesi için; tacirler veya kamu tüzel kişileri aralarında doğmuş veya doğabilecek bir uyuşmazlık olmalı, tarafların üzerinde serbestçe tasarruf edebilecekleri bir konu olmalı, kesin yetki söz konusu olmamalı, yazılı olarak yapılmalı, uyuşmazlığın kaynaklandığı hukuki ilişki belirli veya belirlenebilir olmalı ve yetkili kılınan mahkeme veya mahkemeler bu sözleşmede gösterilmelidir ${ }^{21}$.

Kanunda sayılan bu şartların mevcudiyeti halinde ancak yetki sözleşmesi yapılabilir. Dolayısıyla yetki sözleşmesi açısından bakılması gereken artık kamu düzeni kavramı değil HMK'nun 17. ve 18. maddelerinde belirtilen şartların sağlanıp sağlanmadığıdır. Burada belirtilen şartların dışında kamu düzeni kavramı ile yetki sözleşmesinin yapılıp yapılamayacağının belirlenmesine ihtiyaç kalmamıştır.

\section{B. ORTAK YETKILI MAHKEME}

\section{KAVRAM}

HMK'nun 7. maddesinin birinci fıkrasında davalı tarafta birden fazla kişi bulunması halinde davanın davalılardan birinin yerleşim yerinde görülebileceği düzenlenirken maddenin devamında davalıların tamamı hakkında dava sebebine göre ortak yetkiyi taşıyan bir mahkemenin bulunması durumunda davaya ortak yetkili mahkemede bakılacağı düzenlenmiştir. Mülga 1086 sayılı Hukuk Usulü Muhakemeleri Kanunu hükümlerinde de söz konusu hükümle aynı doğrultudaki hüküm mülga Kanun'un 9. maddesinin ikinci fıkrasında yer almaktaydı.

Ortak yetkili mahkemenin yetkisi, düzenleme değerlendirildiğinde, üç unsurun bulunmasıyla ortaya çıkmaktadır. Ilk olarak davalıların birden fazla olması, ikinci olarak dava sebebinin aynı olması ve üçüncü olarak kanunda ortak yetkili bir mahkemenin söz konusu olması gerekir.

HMK'nun 7. maddesinin birinci fıkrası hükmü HUMK döneminde 9. maddenin ikinci fıkrasındaki hüküm ile paralellik gösterdiğinden HUMK döneminde doktrinde ileri sürülen görüşler halen geçerliliklerini korumaktadır. Bir hukuk normunun değerlendirilmesinde dikkate alınması gereken bir diğer nokta ise o normun uygulanış şeklidir. Bu nedenle öncelikle doktrindeki görüşler daha sonra ise yargı pratiği incelenmeye çalışılacaktır.

21 TANRIVER, Usul, s. 252-254; BUDAK, Yetki Sözleşmesi, s. 2; AŞIK, s. 21; BELGIN GÜNEŞ, s. 200 vd.; AKKAN, Pekcanitez Usul, s. 305-320. 


\section{ORTAK YETKILI MAHKEMEYE İLIŞKIN DOKTRINDEKI GÖRÜŞLER}

Ortak yetkili mahkemeye ilişkin olarak doktrinde bir görüşş; $\mathrm{HMK}^{\prime}$ nun 7. maddesinin birinci fıkrasındaki "Davalı birden fazla ise dava, bunlardan birinin yerleşim yeri mahkemesinde açılabilir. Ancak, dava sebebine göre kanunda, davalıların tamamı hakkında ortak yetkiyi taşıyan bir mahkeme belirtilmişse, davaya o yer mahkemesinde bakılır" şeklindeki düzenlemeyi mutlak bir düzenleme olarak anlamakta ve ikinci cümledeki "bakılır" ifadesinin kesin nitelikte olduğunu ileri sürmektedir. Dolayısıyla bu görüşteki yazarlar; ortak yetkili mahkemenin bulunması durumunda sadece o mahkemede davanın görüleceğini, davalıların herhangi birinin yerleşim yeri mahkemesinde davanın açılamayacağını ve bu mahkemenin kesin yetkili mahkeme olduğunu ifade etmektedirler. Bu görüş doğrultusunda kimi yazarların bazı gerekçelerine değinmek gerekmektedir.

Akkan/Pekcanıtez, HMK'nun 7. maddesinin birinci fıkrasına ilişkin yetki kuralının gerekçe bölümünde 23 "Ancak, birden fazla davalı hakkında dava açılmak istendiğinde, dava sebebine göre davalıların tümü hakkında, kanunda ortak yetkili bir mahkeme belirtilmişse, davanın, davalılardan birinin yerleșim yerinde değil, ortak yetkili mahkemede açılması gerekmektedir. Ayrıca, "...davaya, ancak o yer mahkemesinde bakılır" denilerek, ortak yetkili mahkemenin yetkisi, kesin yetki hâline getirilmiştir" ifadelerine yer verilmiştir. Gerekçe metninde "kesin yetki" ifadesine yer verilmesinden dolayı söz konusu düzenlemenin kesin yetkili mahkemeye ilişkin kural olduğu ileri sürülmektedir ${ }^{24}$.

Yılmaz'a göre, söz konusu düzenlemenin kesin yetki belirttiği açıktır ${ }^{25}$. Ancak bu noktada maddedeki dava sebebi ifadesinden anlaşılanın vakıa olması gereklidir ve taraflar arasındaki bu dava sebebinin davalıların tamamı hakkında aynı olması zorunluluktur. Yazar; dava sebebi olarak vakıadan söz ettikten sonra vakıaların dâhil olduğu hukuki sebebin farklı olması durumunda ortak yetkili mahkemenin yetkisinin ortadan kalkacağını belirtmiştir ${ }^{26}$. Illaveten bu konuda madde gerekçesinde de açık olarak ilgili

22 ATALI/ERMENEK/ERDOĞAN, s. 197; KONURALP, s. 224; TUTUMLU, s. 102-103; AKKAN, Pekcanitez Usul, s. 274; AKIL/PEKSÖZ, s. 29; TAŞ KORKMAZ, s. 1775-1776; YILMAZ E. , s. 325; SOYLU, s. 478; GÖRGÜN, s. 93; ULUKAPI, s. 157-158; KARSLI, s. 267; SÜRAL, s. 171; KILIÇOĞLU, s. 120; ALANGOYA/YILDIRIM/DEREN YILDIRIM, s. 91.

23 HMK Tasarısı'nın 12. maddesi.

24 AKKAN, Pekcanitez Usul, s. 274-278.

25 YILMAZ E. , S. 325.

26 YILMAZ E. , s. 322. 
yetki kuralının kesin olduğu belirtildiğinden kanun koyucunun iradesinin de bu yönde olduğunu belirtmektedir 27 .

Kuru' ya göre, "bakılır" ifadesinin mutlaklığı gereği, diğer davalıların yerleşim yerinde dava açılamaz ${ }^{28}$. Kuru, daha önce, ortak yetkili mahkemede dava açılmaması durumunda, davalılardan birinin yetki itirazında bulunması halinde, sadece itiraz eden taraf hakkında mahkemenin yetkisizlik kararı verilebileceği görüşündeydi. Daha sonra Kuru, maddenin lafzındaki kesinlik, usul ekonomisi ilkesi ve aynı dava sebebi hakkında farklı mahkemelerce çelişik hükümler verilmesinin önlenmesi gibi gerekçelerle bu görüşünden dönmüştür ${ }^{29}$. Yazar, bu durumda davalılardan birinin yetki itirazının söz konusu olmasıyla mahkemenin tüm davalıları etkileyecek bir biçimde yetkisizlik kararı vermesi gerektiğini belirtmiştir.

Doktrindeki kimi yazarlar ise yetki kuralının niteliğine değinmeksizin ortak yetkili mahkemenin bulunması durumunda sadece bu mahkemede davanın görüleceğini ve davalıların herhangi birinin yerleşim yeri mahkemesinde davanın açılamayacağını ileri sürmektedir ${ }^{30}$. Bu görüş zaten yukarıda bulunan görüş ile paralellik arz etmektedir.

Doktrinde farkı bir görüş olarak Bilge/Önen'e göre ise, davalıların birden fazla olması durumunda, davacı, davalılardan birinin yerleşim yeri mahkemesinde dava açabilecektir ve bu durumda diğer davalılar davanın kendi yerleşim yerlerinde açılmasını isteyemeyeceklerdir ${ }^{31}$ (HUMK m. 9/Il; karş. HMK m. 7/l c. 1). Ancak Bilge/Önen'e göre, davalılar hakkında kesin yetkili bir mahkeme varsa kesin yetkili mahkeme ortak yetkili mahkemedir. Dolayısıyla yazara göre; HUMK'nun 9. maddesinin ikinci fıkrasının ikinci cümlesi (karş. HMK m. 7/l c. 2) kesin yetkili bir mahkemeyi düzenlememektedir. Yazara göre, kesin yetkinin bulunduğu durumlar ortak yetkili mahkemeyi doğurmaktadır ${ }^{32}$. Doktrinde Kıyak, Bilge/Önen'in görüşünü değerlendirerek, HMK'nun 7. maddesinin birinci cümlesindeki kural ile davanın davalıların her birinin yerleşim yerinde açılabileceğini, ikinci cümlesindeki kural ile de birinci cümledeki kuralın kesin yetkinin

\footnotetext{
27 YILMAZ E. , s. 328.

28 KURU, Usul, s. 107; KURU, Muhakeme, s. 420.

29 KURU, Muhakeme, s. 421-427.

30 TANRIVER, Usul, s. 234; ARSLAN/YILMAZ/TAŞPINAR AYVAZ/HANAĞASI, s. 210; KURU, Usul, s. 107; KURU, Muhakeme, s. 420-427.

31 BILGE/ÖNEN, s. 182.

32 BILGE/ÖNEN, s. 183; BERKIN, s. 77.
} 
bulunduğu davalara tesirinin engellenmesinin amaçladığını ve bu görüşün isabetli olduğu kabul edildiği takdirde tartışmaların son bulacağını ileri sürmektedir ${ }^{33}$. Ayrıca HMK'nun ortak yetkili mahkemeye ilişkin kuralının, kesin olmayan özel yetki kurallarına etki eden bir kural olmadığını ileri sürmüştür ${ }^{34}$.

Doktrinde ifade edilen diğer bir görüş̧ ${ }^{35}$ göre ortak yetkili mahkemenin yetkisi kesin yetki kuralı niteliğinde değildir. Budak/Karaaslan'a göre kanunda bir dava için gösterilmiş tek yetkili mahkemenin olması o mahkemeyi kesin yetkili hale getirmez, resen mahkeme tarafından bu hususun dikkate alınmasını gerektirmez. Dolayısıyla ortak yetkili mahkeme kuralı yetki sözleşmesi yapılmasına engel teşkil etmemekte$\operatorname{dir}^{36}$. Nitekim bu husus genel yetkili mahkemeyi belirten düzenlemenin niteliğinden de anlaşılmaktadır ${ }^{37}$.

Umar'a göre; ortak yetkili mahkemenin yetkisi doktrinde sakıncalı bir biçimde çoğunluk tarafından kesin yetki şeklinde nitelendirilmektedir. Kesin yetki şeklindeki kabulün en önemli sakıncası davanın taraflarına yönelik meşakkatli ve masraflı bir yetki kuralı getirilmesidir ${ }^{38}$.

Bir diğer görüşe göre ${ }^{39}$ ise $\mathrm{HMK}^{\prime}$ nun 7. maddesinin ikinci fıkrasında belirtilen yetki kuralı kesin yetki kuralı değildir. Ancak ortak yetkili mahkemenin yetkisi, kesin yetki kuralına yaklaşan bir yetki kuralıdır. Ortak yetkili mahkemede davanın görülmesi gerektiğine yönelik itirazlar, yetki ilk itirazı niteliği taşır. Yazar’a göre davalıların birden fazla olduğu bir davada davalılardan birinin yerleşim yerinde dava açılmışsa dava arkadaşlı̆ının türüne göre hâkim karar vermelidir. Mecburi dava arkadaşlığı söz konusuysa davalılardan birinin davanın ortak yetkili mahkemede görülmesi gerektiği yönünde yaptığı yetki ilk itirazı üzerine mahkeme tüm davalıları etkileyecek biçimde yetkisizlik kararı vermelidir. intiyari dava arkadaşlığının bulunduğu bir durum gerçekleşirse sadece ilk itirazda bulunanı etkileyecek biçimde yetkisizlik kararı verilmelidir. Ancak yazara göre olması gereken hukuk bakımından dava arkadaşlığııın türü gözetilmeksizin yetki ilk itirazı çerçevesinde davalıların tamamını etkileyecek şekilde yetkisizlik kararı verilebilmelidir.

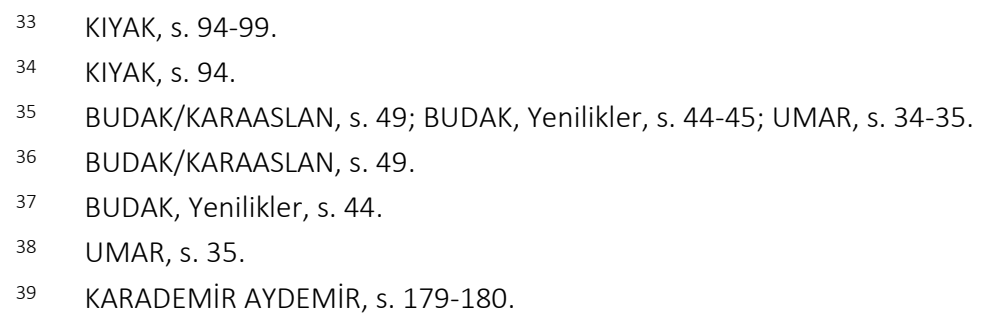




\section{ORTAK YETKILI MAHKEMEYE ILISSKIN YARGI KARARLARI}

Ortak yetkili mahkeme konusunda yargı kararlarının çoğu haksız fiilden doğan davalardaki ortak yetkili mahkemeye ilişkindir. Bir kararında Yargıtay şu şekilde içtihat etmiştir; "HMK'nın 16. madde hükmü, HUMK'taki düzenlemeye oranla daha genişletilmiş ve ayrıntılandırılmıştır. Ancak, HMK'da kesin yetki halleri açıkça sayılmış olup, haksı fiile dair davalardaki yetki, kesin yetki olmayıp, bir seçimlik yetkidir. Ortak yetkili mahkemede dava açılmasının zorunlu olması durumu, ancak zorunlu dava arkadaşlığına dair hükümlerin varlığı halinde uygulanır”40. Görüldüğü gibi bu kararda Yargıtay, ortak yetkili mahkemenin özellikle davalılar arasında zorunlu dava arkadaşlığın olması durumunda uygulanabilir olduğunu ve bunun dışında davalılar arasında ihtiyari dava arkadaşlığının olduğu durumlarda seçimlik yetkinin davacının elinden alınamayacağını belirtmiştir.

Yargıtay, Tüketicinin Korunması Hakkındaki Kanun'dan kaynaklanan bir uyuşmazlıkla ilgili olarak HMK'nun 7. maddesindeki ortak yetkili mahkemeye ilişkin kuralın, özel kanunlarda yazan yetki kurallarını değiştirmeyeceğini ve bu nedenle Tüketicinin Korunması Hakkındaki Kanun'dan kaynaklanan yetki kurallarına göre davacının seçimlik yetkisinin bertaraf edilemeyeceğini belirtmiştir ${ }^{41}$.

$40 \quad$ Y. 17 HD, T. 10.02.2014, E. 2014/541 K. 2014/1462: Kazancı.

41 "Davacı... Hastaneye sevk edilerek ameliyata alındığını ileri sürerek; fazlaya dair hakları saklı kalarak, kalıc maluliyet kaynaklı maddi zararının tespit ve tazminini, geçici tam iş göremezlik süresi maddi zararının tespit ve tazminini, geçici tam iş göremezlik süresi sebebiyle bakıcı yardımo gideri maddi zararının tespit ve tazmininin hatalı tıbbi müdahale tarihinden itibaren işleyecek ticari avans faizi ile birlikte müștereken ve müteselsilen davalılardan tahsiline karar verilmesini istemiştir...HMK'nun "Davalının birden fazla olması hâlinde yetki" başlıklı 7/1 maddesine göre, davalı birden fazla ise dava, bunlardan birinin yerleşim yeri mahkemesinde açılabilir. Ancak, dava sebebine göre kanunda, davalıların tamamı hakkında ortak yetkiyi taşıyan bir mahkeme belirtilmişse, davaya o yer mahkemesinde bakılır. 6502 Sayılı TKHK'nun 73/5. maddesinde ise, "Tüketici davaları, tüketicinin yerleşim yerinin bulunduğu yerdeki tüketici mahkemesinde de açılabilir." düzenlemesi mevcuttur. Yetkiye dair bu düzenlemeler seçimlik olup, tüketici isterse kendi yerleşim yerindeki isterse davalıların yerleşim yerlerinin birindeki tüketici mahkemelerinde dava açabilir. Somut olayda davacının yerleşim yeri Kırıkhan olduğuna göre Asliye Hukuk Mahkemeleri (Tüketici Mahkemeleri) de yetkilidir. Hal böyle olunca davanın yetkili mahkemede açıldığının kabulüyle işin esasına girilerek uyuşmazlığın çözülmesi gerekirken, yazılı şekilde yetkisizlik kararı verilmesi usul ve yasaya aykırı olup bozmayı gerektirir..." (Y. 13. HD, T. 27.09.2017, E. 2016/26310 K. 2017/8668; aynı yönde bkz. Y. 13. HD, T. 14.01.2016, E. 2015/34596 K. 2016/418; Y. 13. HD, T. 05.10.2016, E. 2016/15438 K. 2016/17745: Kazancı). 
Yargıtay, iş hukukundan kaynaklanan uyuşmazlıklarda davacının seçimlik yetkisinin elinden alınamayacağını belirtmiştir ${ }^{42}$. Mülga 5521 sayılı İş Mahkemeleri Kanunu'nun yetkiye ilişkin kuralları yargı kararlarında kamu düzeninden ve seçimlik bir yetki kuralı olarak kabul edilmekteydi. Dolayısıyla ortak yetkili mahkemeye ilişkin yetki kurallarının bu davalara uygulanmayacağı kabul edilmişti ${ }^{43}$. İş kazalarından doğan davalarda ortak kesin yetkili mahkemenin uygulanması gerektiği ilk derece mahkemeleri tarafından ileri sürülse de bu Yargıtay kararlarında kabul görmemekteydi. İş mahkemelerine ilişkin yetki kuralının düzenlendiği 7036 sayılı İş mahkemeleri Kanunu'nun 6. maddesinde mahkemelerin yetkisi kapsamlı bir biçimde düzenlenmiştir. 7036 sayılı Iş Mahkemeleri Kanunu bu hususu haksız fiilden doğan davalardaki yetki kuralına benzer olarak "...Davalı birden fazla ise bunlardan birinin yerleşim yeri mahkemesi de yetkilidir. Iş kazasından doğan tazminat davalarında, iş kazasının veya zararın meydana geldiği yer ile zarar gören iş̧̧inin yerleşim yeri mahkemesi de yetkilidir" şeklinde düzenlemiş ve ortak yetkili mahkeme olarak algılanabilecek bir düzenlemeye yer vermemiştir. Önceki düzenlemede yer alan "Bu madde hükümlerine aykırı yetki sözleşmeleri geçersizdir." hükmüne 7036 sayılı Kanun'da da yer verilmiştir.

42 "...Dava işçilik alacaklarının tahsili istemine ilişkindir. 5521 Sayılı iş Mahkemeleri Kanununun 5. maddesi uyarınca, iş mahkemelerinde açılacak her dava, açıldığı tarihte dava olunanın Türk Medeni Kanunu gereğince ikametgâhı sayılan yer mahkemesinde bakılabileceği gibi, iş̧̧inin işini yaptığı işyeri için yetkili mahkemede de bakılabilir. Bunlara aykırı sözleşme geçerli değildir. Davalı işverenlerin adresleri istanbul olup davacının, iş sözleşmesinden kaynaklanan davasını istanbul Anadolu iş Mahkemesinde açtığı sabittir. Davacı tarafından 5521 Sayılı Kanun'un 5. maddesi uyarınca davalı işverenin ikametgahı yer mahkemesinde davanın açıldığı, dolayısıyla davaya konu uyuşmazlığın çözümünde yetkili mahkemenin Istanbul Anadolu iş Mahkemesi olduğu sonucuna varılmıştır. Bununla birlikte 6100 Sayılı Hukuk Muhakemeleri Kanunun 7. maddesinde davalının birden fazla olması halinde yetkili mahkemenin düzenlendiği, buna göre de dava sebebine göre kanunda davalıların tamamı hakkında ortak yetkiyi taşıyan mahkemenin belirtilmesi halinde davaya o yer mahkemesinde bakılacağı belirtilmiştir. Ancak söz konusu ortak yetkili mahkemenin iş mahkemesinin yetkisinin tespitinde uygulanma kabiliyeti bulunmamaktadır. Çünkü 5521 Sayılı Kanun'un 5. maddesinde düzenlenen yetki kuralları ile işşiye davasını açacağı yetkili mahkeme konusunda seçimlik hak tanınmış olup davacı iş̧̧inin bu hakkını davalıların davanın açıldığı tarihteki ikametgah adresinin bağı bulunduğu istanbul Anadolu iş Mahkemesin-de dava açmakla kullandı̆̆ı anlaşılmıştır. Kaldı ki 5521 Sayılı Kanun'un 5. maddesiyle düzenlenen yetki kurallarının 6100 Sayılı Hukuk Muhakemeleri Kanununun yetki kurallarına göre özel nitelikte hükümler olduğu da açıktır. Hal böyle olunca iş mahkemesinin yetkisi belirlenirken 6100 Sayılı Hukuk Muhakemeleri Kanununun 7. maddesinin uygulanması mümkün olmayıp yerel mahkemece aksine gerekçelerle direnme kararı verilmesi isabetsizdir." (Y. HGK, T. 29.03.2017, E. 2014/9-2163 K. 2017/555: Kazancı).

43 Y. HGK, T. 29.03.2017, E. 2014/9-2163 K. 2017/555; aynı yönde bkz. Y. 7. HD, T. 10.11.2016, E. 2016/19400 K. 2016/19226; Y. HGK, T. 22.11.2017, E. 2015/21-3679 K. 2017/1410: Kazancı. 
Yargıtay, ortak yetkili mahkemeye ilişkin yetki kuralının kesin yetki kuralı olmadığına ve yetki ilk itirazı şeklinde yetki kurallarına aykırılığın ileri sürülebileceğine karar vermektedir ${ }^{44}$. Ortak yetkili mahkemenin olması durumunda yetki sözleşmesi yapılabileceğini de karara bağlamıştır ${ }^{45}$.

\section{HAKSIZ FIILDEN DOĞAN DAVALARDA ORTAK YETKILI MAHKEME}

\section{A. KAVRAM}

Türk Borçlar Kanunu'nun 49. maddesinin birinci fıkrasında haksız fiilden doğan sorumluk; "Kusurlu ve hukuka aykırı bir fillle başkasına zarar veren..." şeklinde ifade edilerek kusurlu ve hukuka aykırı zarar verici bir davranışın haksız fiil sorumluluğuna neden olacağı düzenlenmiştir. Haksız fiilin unsurları arasında kusur bulunsa da kanun koyucu istisnai olarak bazı durumlarda kusur şartını aramamışıı. Bu tür kusursuz sorumluluk türleri de haksız fiilden doğan davalar içerisinde yer almaktadır ${ }^{46}$. Haksız fiile uğrayan kişinin uğradığı zarara ilişkin hukuki korunma talepleri haksız fiilden doğan davalara vücut vermektedir ${ }^{47}$.

Gerek HMK gerekse HUMK hükümlerinde haksız fiilden doğan davalarda yetkili mahkeme ayrıca düzenlenmiştir. HUMK' nun 21. maddesinde yer alan düzenleme "Haksız bir fillden mütevellit dava o filin vuku bulduğu mahal mahkemesinde ikame olunabilir" şeklindeydi. HMK ise bu yetki kuralının kapsamını genişleterek 16. maddesinde "Haksız fiilden doğan davalarda, haksız filin işlendiği veya zararın meydana geldiği yahut gelme ihtimalinin bulunduğu yer ya da zarar görenin yerleşim yeri mahkemesi de yetkilidir" denilmek suretiyle düzenlemiştir.

HUMK döneminde lafızda yer alan "haksız filin vuku bulduğu mahal" ifadesinden ne anlaşılması gerektiği tartışılmış ve bu tartışmaların HMK'nun 16. maddesinde "haksız fililin işlendiği yer mahkemesi" ifadesinde de devam ettiği gözlemlenmektedir. Doktrindeki hâkim görüşe göre "haksız fiilin vuku bulduğu mahal" ifadesinden haksız fiilin esaslı unsurlarından birinin gerçekleştiği her yer anlaşılması gerekir ${ }^{48}$. Bu tartışmanın önemi esasen HUMK'nun 21. maddesinde düzenlenen yetki kuralının yoruma açık olmasından kaynaklanmaktaydı. HMK'nun 16. maddesinde ise yetkili mahkeme-

\footnotetext{
44 Y. 4. HD, T. 14.05.2014, E. 2013/18688 K. 2014/7747; aynı yönde bkz. Y. 13. HD, T. 29.041987, E. 1987/1641 K. 1987/2607: Kazancı.

45 Y. 13. HD, T. 25.04.2017, E. 2017/4464 K. 2017/4967: Kazanc1.

46 OĞUZMAN/ÖZ, s. 1-10; EREN, s. 509-510; AKKAN, Pekcanıtez Usul, s. 288-289; YILMAZ E. , s. 442; ALANGOYA/YILDIRIM/DEREN YILDIRIM, s. 100.

47 Örneğin; TMK m. 24 ve 25 gereği korunma halleri TANRIVER, Usul, s. 243.

48 ALANGOYA, s. 110; ÜSTÜNDAĞ, s. 227; BILGE/ÖNEN, s. 199.
} 
ler genişletilmeye çalışılmıştır. Ancak HMK'nun 16. maddesindeki "haksız fiilin işlendiği yer mahkemesi" ifadesinden doktrinde ifade edildiği üzere "hukuka aykırı davranışın işlendiği yer" olduğunun anlaşılması gerekmektedir ${ }^{49}$.

\section{B. HAKSIZ FIILDEN DOĞAN DAVALARDA ORTAK YETKILI MAHKEMEYE ILIŞKIN DOKTRINDEKI GÖRÜŞLER}

HMK'nun 16. maddesindeki düzenlemenin lafzından haksız fiilden doğan davalarda yetkili mahkemelerin "haksı fiilin işlendiği yer mahkemesi", "zararın meydana geldiği yer mahkemesi", "zararın meydana gelme ihtimalinin bulunduğu yer mahkemesi" ve "zarar görenin yerleşim yeri mahkemesi" olduğu anlaşılmaktadır. Söz konusu düzenleme, haksız fiil suretiyle zarar gören kişinin hukuki korunma talebini yönelteceği yargı organlarına ulaşmasını kolaylaştırmayı amaçlamaktadır ${ }^{50}$.

Doktrinde hâkim olan görüşe göre, haksız fiilden doğan davalardaki yetki kuraIının niteliğinin kamu düzeninden olmadığı yönündedir ${ }^{51}$. Nitekim haksız fiilden doğan davalarda, genel yetki kuralı olan davalının yerleşim yeri mahkemesi de halen yetkili$d i^{52}$. Söz konusu yetki kuralının hukuki niteliği ise kanunun lafzının seçimlik yetki şeklinde düzenlenmesinden de anlaşılacağı üzere kesin olmayan yetki kuralıdır ${ }^{53}$. Davalı tarafta bir kişinin yer alması durumunda yetkili mahkemenin tayini sorun oluşturmayacaktır.

Çalışmamızın konusunu teşkil eden husus HMK'nun 7. maddesinin birinci fıkrasının ikinci cümlesinde yer alan “...dava sebebine göre kanunda, davalıların tamamı hakkında ortak yetkiyi taşıyan bir mahkeme belirtilmişse, davaya o yer mahkemesinde bakılır" şeklindeki düzenlemenin haksız fiilden doğan davalara ilişkin öngörülen yetki kurallarının uygulamasını ve bunların hukuki niteliğini etkileyip etkilemeyeceğidir. Davalı tarafta haksız fiil sorumluluğu çerçevesinde birden fazla kişinin yer almadığı durumlarda haksız fiile ilişkin yetki kuralı tali, kesin olmayan ve tarafların üzerinde serbestçe tasarruf edebileceği bir yetki kuralı düzenlemesidir.

Ortak yetkili mahkemenin söz konusu olması durumunda, yani davalıların birden fazla olması durumunda, yetki kuralının hukuki niteliğine ilişkin olarak doktrinde

\footnotetext{
49 TANRIVER, Usul, s. 243.

50 TANRIVER, Usul, s. 242.

51 YILMAZ E. , s. 451; KURU, Usul, s. 113; KURU, Muhakeme, s. 486; aksi yönde olması gerektiğini belirten görüş için bkz. YILMAZ M. , s. 15.

52 KURU, Usul, s. 113; YILMAZ E. , s. 462; POSTACIOĞLU/ALTAY, s. 136; KURU, Muhakeme, s. 382.

53 ATALI/ERMENEK/ERDOĞAN, s. 213; TANRIVER, Usul, s. 243; BUDAK/KARAASLAN, s. 52; ARSLAN/YILMAZ/TAŞPINAR AYVAZ/HANAĞASI, s. 213; AKKAN, Pekcanıtez Usul, s. 286-289; KARSLI, s. 272; YILMAZ E. , s. 462.
} 
çeşitli görüşler yer almaktadır. Bir görüşe $\mathrm{e}^{54}$ göre davalı tarafta birden fazla kişi olan ve haksız fiilden doğan bir dava söz konusuysa ortak yetkili mahkemenin yetkisi, kesin yetki kuralı niteliğindedir.

Akkan/Pekcanıtez'e göre haksız fiilin birden fazla kişi tarafından işlenmesi durumunda haksız fiilin vuku bulduğu yer mahkemesinin yetkisi kesin yetki niteliğinde$\mathrm{dir}^{55}$. HMK' nun 7. maddesinin gerekçesinde ortak yetkili mahkemenin yetkisinin kesin yetki şeklinde belirtilmesi kanun koyucunun iradesini yansıtmaktadır. Davalıların tamamı hakkında haksız fiil hükümlerine değil de başka hukuki sebeplere başvurulabilmesi ortak yetkili mahkeme kuralının uygulanmasına engel teşkil etmeyecektir. Aynı fiilden dolayı davalıların birine haksız fiil sorumluluğundan, diğerine de sözleşmeye aykırılığa gidilebilmesi durumunda uyuşmazlığın hukuki sebebinin değişmesi söz konusu olduğundan haksız fiildeki ortak yetkili mahkemeye başvurulabilecektir ${ }^{56}$. Bu durumda davalıların her birinin yerleşim yeri mahkemesi yetkili değildir ve ortak yetkili mahkemenin yetkisinin hukuki niteliği gereği yetki kuralına aykırılık hâkim tarafından resen nazara alınabilir ${ }^{57}$.

Yılmaz'a göre; ortak yetkili mahkemenin yetkisi kesin yetki kuralıdır. Bu, maddenin gerekçesinden de anlaşılabilmektedir. Ancak ortak yetkili mahkemenin yetkisi kesin nitelikte olmasına rağmen bu zarar gören davacının yerleşim yerinde davanın açılmasına engel teşkil etmemektedir ${ }^{58}$. Yazara göre, ortak yetkili mahkemenin bulunması zorunlu dava arkadaşığı ile doğrudan ilişkili değildir. Zorunlu dava arkadaşlığını bulunması durumunda ortak yetkili mahkemede dava açılabilmesinin yanı sıra davalılardan birinin yerleşim yerinde de dava açılabilir ${ }^{59}$. Yazar, davalıların tamamı hakkında aynı dava sebebinin (vakıa) olması durumunda ortak yetkili mahkemenin kesin yetkili olduğunu ifade etmektedir. Ancak davalıların bir kısmına karşı haksız fiilden hükümlerine dayanılarak diğer kısmına ise sözleşmeye aykırılık hükümlerine dayanılarak mahkemeye başvurulmuşsa ortak yetkili mahkeme kuralının bu durumda uygulanmayacağını belirtmektedir60. Ayrıca yazar, ortak yetkili mahkeme kuralı sadece haksız fiilden doğan davalarda değil; söz konusu kuralın işçi alacaklarının tahsili

\footnotetext{
54 AKKAN, Pekcanıtez Usul, s. 288; YILMAZ E. , s. 325.

55 AKKAN, Pekcanitez Usul, s. 288.

56 AKKAN, Pekcanıtez Usul, s. 275.

57 AKKAN, Pekcanitez Usul, s. 275.

58 YILMAZ E., s. 325.

59 YILMAZ E. , s. 325.

60 YILMAZ E. , s. 322.
} 
gibi davalarda da uygulanabileceğine değinmiştir ${ }^{61}$. Ortak yetkili mahkeme haksız fiilden doğan davalarda somut olayın özelliklerine göre; "haksız fiilin işlendiği yer mahkemesi", "zararın meydana geldiği yer mahkemesi" veya "zararın meydana gelme ihtimalinin bulunduğu yer mahkemesi" olabilir62. Ortak yetkili mahkeme kuralının uygulanması gereken davalarda yetki itirazı her aşamada ileri sürülebileceği gibi hâkim tarafından da resen dikkate alınabilecektir ${ }^{63}$.

Doktrinde başka bir görüşe ${ }^{64}$ göre ise; haksız fiilden doğan davalarda ortak yetkili mahkemenin yetkisinin kesin yetki kuralı olmadığı yönündedir. Bu görüşteki yazarların gerekçelerine değinmek gerekirse;

Budak/Karaaslan'a göre bu görüş; maddenin lafzında kesin yetkilidir ifadesine yer verilmemesi ve tek yetkili mahkemenin gösterilmesinin kesin yetkili mahkemenin düzenlendiği anlamına gelmemesi gibi nedenlerle savunulabilir. Dolayısıyla şartları varsa bu durumda yetki sözleşmesi yapılmasının mümkün olduğunu ve bu yetki kuralına aykııııkların yetki ilk itirazı yoluyla ileri sürülebileceğini ifade etmiştir ${ }^{65}$. HMK'nun 16. maddesindeki yetkili mahkemelerden ortak yetkili mahkeme teşkil eden mahkemelerde davanın açılabileceği ifade edilmiştir.

Umar'a göre, bu yetki kuralının kesin yetkili mahkeme olarak anlaşıması bazı sakıncalar meydana getirmektedir. Haksız fiilin işlendiği yer mahkemesinin davalılar arasında ortak kesin yetkili yer mahkemesi olarak kabulü söz konusu davalardaki yetki kuralının amacına uygun düşmeyecektir ${ }^{66}$.

Doktrindeki bir başka görüşe göre ise, HMK'nun 7. maddesinde düzenlenmekte olan ortak yetkili mahkeme kuralı nitelik itibariyle kesin yetki kuralıdır67. Ancak haksız fiilden doğan davalara bu yetki kuralı uygulanmamalıdır. Haksız fiilden doğan davalarda davalıların birden fazla olması halinde kesin olmayan yetki kuralları geçerlidir. Dolayısıly bu davalarda HMK'nun 16. maddesindeki mahkemelerin yetkisi ve HMK'nun 7. maddesine göre davalıların yerleşim yeri mahkemelerinin de yetkisi bulunmalıdır ${ }^{68}$.

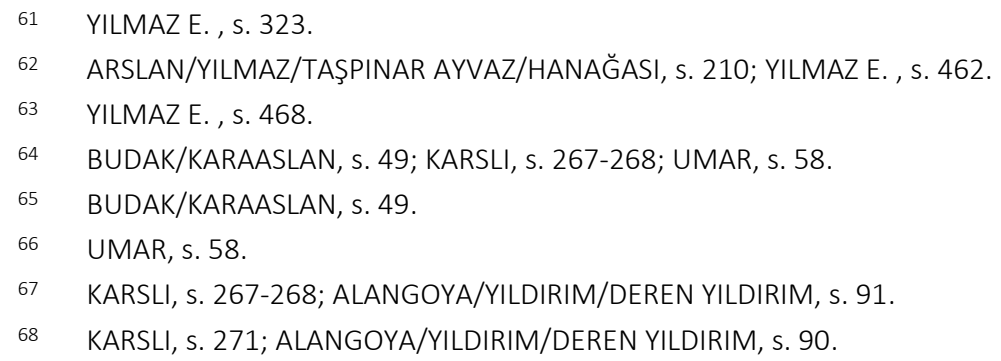


Tüm bu görüşlerin yanı sıra Postacıoğlu ve Berkin bu konuya ilişkin olarak haksız fiilden doğan davalarda yetki kurallarının değerlendirilip açılacak davada ortak yetkili mahkeme niteliğinde olanın tercih edilmesi gerektiğini ifade etmişlerdir ${ }^{69}$.

Doktrinde Bilge/Önen; "dava birden fazla kişiye karşı açılırsa davacı davalılardan birinin yerleşim yeri mahkemesinde davayı açarak seçimlik yetki kuralına uymuş olur" diyerek davalıların bu hususa ilişkin yetki itirazını ileri süremeyeceğini belirtmiş ve devamında haksız fiilden doğan davalar örneğini vermiştir ${ }^{70}$. Daha önce açıklandığı üzere Bilge/Önen, ortak yetkili mahkeme kavramının kanun koyucunun kesin yetki olarak düzenlediği gayrimenkulün aynından doğan davalardaki, terekeden doğan davalardaki gibi halleri ifade ettiğini belirtmektedir ${ }^{71}$.

\section{HAKSIZ FIILDEN DOĞAN DAVALARDA ORTAK YETKILI MAHKEME ILE ILGILI YARGI KARARLARI}

Ortak yetkili mahkeme kuralının, yargı kararlarında genellikle haksız fiilden doğan davalar bakımından ele alındığı gözlenmekle birlikte diğer bazı davalarda da söz konusu düzenleme değerlendirilmektedir ${ }^{72}$.

Bir bölge adliye mahkemesi; ilk derece mahkemesinin trafik kazasından kaynaklı haksı fiilden doğan bir davada, kazanın meydana geldiği yer mahkemesinin HMK'nun 7. maddesi uyarınca ortak yetkili mahkeme olduğu gerekçesiyle yetkisizlik kararı vermesini isabetli bulmamıştır. İstinaf incelemesi esnasında davalılardan birinin yerleşim yerindeki mahkeme olan ilk derece mahkemesinin yetkisizlik kararı vermesi yerine işin esasına girip uyuşmazlığı karara bağlaması gerektiğinden bahisle, ilk derece mahkemesi kararının kaldırılmasına ve yargılamanın devam edilmesi için yetkili olan mahkemeye gönderilmesine karar verilmiştir ${ }^{73}$.

Bir başka bölge adliye mahkemesi kararında; haksı fiilden doğan davalarda ortak yetkili mahkeme kuralının uygulanabilmesi için dava sebebinin aynı olması ile anlaşılması gerekenin haksız fiilin davalılar tarafından işlenmesi durumu olduğu şeklinde belirleme yapmıştır. Kararda her ne kadar dava, davalılar açııından haksız fiilden doğan dava olarak nitelendirilebilse de haksız fiili işleyen ile sözleşmesel sorumluluğu

\footnotetext{
69 POSTACIOĞLU/ALTAY, s. 136-137; POSTACIOĞLU, s. 167; BERKIN, s. 82.

70 BILGE/ÖNEN, s. 182.

71 BILGE/ÖNEN, s. 183; aynı yönde bkz. KIYAK, s. 98.

72 Bkz. yukarıda I, B, 3.

73 ìst BAM 9. HD, T. 28.06.2018, E. 2018/613 K. 2018/1008; aynı yönde bkz. İst BAM 17. HD, T. 16.05.2018, E. 2018/542 K. 2018/868: Kazancı.
} 
bulunan tarafın davalı tarafta yer aldığı uyuşmazlıkta ortak yetkili mahkeme kuralının uygulanamayacağı belirtilmiştir ${ }^{74}$.

İ̧ kazasından kaynaklı tazminat davasına ilişkin bir bölge adliye mahkemesi kararında; haksız fiilden doğan davalarda ortak yetkili mahkemenin kesin yetki niteliği taşımadığı belirtilmiştir. Illaveten de "iş mahkemelerinin yetkisinin kamu düzenine ilişkindir" kabulü dolayısıyla ortak yetki kuralının iş mahkemelerinde geçerli olmadığına karar verilmiştir ${ }^{75}$.

Ortak yetkili mahkemeye ilişkin Yargıtay bir kararında; ilk derece mahkemesinin somut olayda uyuşmazlığın haksız fiilden doğduğundan bahisle davanın ortak yetkili kesin mahkemede görülmesi gerektiği şeklindeki kararını bozmuştur. Söz konusu olayda sözleşmeden doğan bir davanın bulunduğunu belirterek ortak yetkili mahkemeye ilişkin yetki kurallarının işlerlik kazanmayacağını belirtmiştir ${ }^{76}$.

Yargıtay, haksız fiilden doğan davalarda davalıların birden fazla olması durumunda ortak yetkili mahkemenin kesin yetkili mahkeme olarak algılanmaması gerektiğini ${ }^{77}$ ve HMK sistematiğinde kesin yetkili mahkemelerin hangileri olduğunun açıkça

74 ist BAM 8. HD, T. 17.05.2018, E. 2017/758 K. 2015/511: Kazancı.

75 Sam. BAM 7. HD, T. 12.06.2017, E. 2017/1699 K. 20171238: Kazancı.

76 "...davacının kendi ikametgahında dava açtığı, davalıların yerleşim yerleri ile haksız fillin meydana geldiği yerin birbirinden farklı olduğu, HMK 7/1 maddesine göre, davalı birden fazla ise dava bunlardan birinin yerleşim yeri mahkemesinde dava açılabileceği, ancak dava sebebine göre kanunda davalıların tamamı hakkında ortak yetkiyi taşıyan bir mahkeme belirtilmiş ise davaya o yer mahkemesinde bakılacağı, maddenin ifadesinden yetkinin kesin olduğunun anlaşıldığı, HMK 7/1 maddesinin hükümet gerekçesinde de (madde 12) öngörülen yetki kuralının kesin yetki kuralı olduğunun vurgulandığı, somut olayda ... Mahkemeleri'nin haksız fillin vuku bulduğu yer mahkemesi olarak tüm davalılar yönünden ortak yetkiyi taşıyan mahkeme olduğu anlaşıldığından, dosyanın yetkili ... Asliye Ticaret (Hukuk) Mahkemesine gönderilmesine karar verilmiş, hüküm davacı vekilince temyiz edilmiştir.

Dava, satış sözleşmesine istinaden alıcıya verilen mal bedelinin tahsili istemine ilişkindir. Davacı ile davalılardan ....A.Ş. arasında geçmişe dayalı satış işleminin bulunduğu, diğer davalılardan Ismet Merde'nin ise davalı....A.S. adına nakliye yaptığı dosyadaki belgelerden anlaşılmaktadır. Taraflar arasında sözleşme ilişkisi bulunmaktadır. Hal böyle olunca, mahkemece taraflar arasındaki sözleşme ilişkisinin varlığı kabul edilerek BK.'nun 73. maddesi (TBK.'nun 89. maddesi J uyarınca, davacının ikametgâhı mahkemelerinin yetkili olduğu gözetilerek, işin esası hakkında taraf delilleri toplanıp sonucuna göre bir karar verilmesi gerekirken eksik inceleme ile yazılı şekilde karar verilmesi isabetsiz olup bozmayı gerektirmiştir..." (Y. 19. HD, T. 19.06.2017, E. 2016/9794 K. 2017/5168; Y. HGK, T. 29.03.2017, E. 2014/9-2163 K. 2017/555: KazancI).

77 “...6100 Sayılı HMK'nın haksız fiillerde yetkiyi düzenleyen 16. maddesinde HMK'nın 7/1-2. cümlesindeki düzenleme anlamında kesin yetki söz konusu değildir. Haksız fiil halinde HMK'nın 16. maddesi gereğince birden fazla mahkemenin yetkili kılınarak davacıya bir seçimlik hak tanınmış olduğu göz önüne alındığında, davacı, bu mahkemelerden birinde dava açmak hususunda seçimlik hakka sahiptir..." (Y. 20. HD, T. 22.10.2018, E. 2018/4972 K. 2018/6685; aynı yönde 
belirtildiğini içtihat etmektedir ${ }^{78}$. Nitekim bir kararında; söz konusu yetki kuralının kesin yetki kuralı olduğuna ilişkin ibarenin kanunun lafzında yer almaması, gerekçenin kuralın niteliğinin tayininde esas alınamayacağı, haksız fiile ilişkin yetki kurallarının kamu düzenine ilişkin yetki kuralları niteliğinde olmaması ve HMK'nun 16. maddesindeki yetki kuralı kesin olmayan yetki kuralı niteliğinde olması gibi gerekçelerle ortak yetkili mahkeme kuralının kesin yetki kuralı niteliği taşımadığını ayrıntılı olarak açıklayarak karara bağlamıştır ${ }^{79}$.

\section{HAKSIZ FiiLDEN DOĞAN DAVALARDA ORTAK YETKILI MAHKEMEYE ILIŞKIN DE- ĞERLENDIRMEMIZ}

Yukarıdaki açıklamalarımızda ortak yetkili mahkemeye ilişkin olarak doktrin tarafından yapılan değerlendirmelere ve yargı kararlarındaki pratiğe değinilmiştir. Ortak yetkili mahkeme düzenlemesine yönelik değerlendirmelerimizi bu bölümde gerekçelendirerek açıklamak gerekmektedir.

HMK'nun 7. maddesinin birinci fıkrası, HUMK dönemindeki haliyle olduğu gibi korunmuş bir düzenlemedir. HMK'nun 7. maddesinin birinci fıkrasının ilk cümlesi, özellikle davalıların birden fazla olması ve bunlardan birinin yerleşim yerinde dava açıması durumunda davalılardan birinin yetki itirazını engelleyici bir işlevi vardır. Özellikle intiyari dava arkadaşlığı durumunda dava arkadaşlarından birisi, davanın kendi yerleşim yerinde açılmadığı gerekçesiyle yetki ilk itirazında bulunamayacaktır. Şayet bu hüküm olmasaydı davalılardan birisinin yetki itirazı üzerine o davalı hakkında yetkisizlik kararının verilmesi gerekecekti ve ihtiyari dava arkadaşlığı bir itirazla ortadan kaldırılabilecekti. Dolayısıyla HMK'nun 7. maddesinin birinci fıkrasının bu ilk cümlesinin son derece önemli bir işlevi vardır. Burada tartışılması gereken husus, HMK'nun 7. maddesinin birinci fıkrasının ikinci cümlesidir. Sorunlar bu ikinci cümlenin kesin yetki kuralı teşkil edip etmemesi noktasında toplanmaktadır.

Ilk olarak HMK'nun 7. maddesinin birinci fıkrası "Davalı birden fazla ise dava, bunlardan birinin yerleşim yeri mahkemesinde açılabilir. Ancak, dava sebebine göre kanunda, davalıların tamamı hakkında ortak yetkiyi taşıyan bir mahkeme belirtilmişse, davaya o yer mahkemesinde bakılır." şeklinde olduğundan ortak yetkili mahkemeye yönelik düzenlemenin "bakıır" ifadesiyle sona ermesi mutlaklık ifade ettiği

bkz. Y. 20. HD, T. 10.04.2017, E. 2017/5413 K. 2017/3036; Y. 20. HD, T. 22.10.2018, E. 2018/4972 K. 2018/6685: Kazancı).

78 Y. 11. HD, T. 24.11.2014, E. 2014/16419 K. 2014/18212; aynı yönde bkz. Y. 11. HD, T. 04.02.2013, E. 2013/624 K. 2013/1833; Y. 4. HD, T. 02.07.2013, E. 2013/10027 K. 2013/12681: Kazancı.

79 Y. HGK, T. 27.05.2015, E. 2013/11-2359 K. 2015/1443; Lexpera. 
doktrinde belirtilmektedir. Dolayısıyla söz konusu yetki kuralının hukuki niteliğini kesin yetki kuralı olarak anlamak gerektiği ileri sürülmektedir ${ }^{80}$. HMK'nun yetki kurallarına ilişkin düzenlemelerinde; bir yetki kuralının kesin yetki niteliğinde olduğu açıkça belirtilmediği sürece, o yetki kuralı kesin olmayan yetki kuralı niteliğindedir. Kesin olmayan yetki hallerinde kural olarak genel yetkili mahkemenin yetkisi halen devam etmektedir. Ancak irtibat noktalarının önemi ve niteliğine göre özel yetki kuralları veya kesin yetki kuralları istisnai olarak belirtilmiştir. HMK'nda kesin yetkinin istisnailiği ve kesin yetkili durumların açıkça belirtilmesi göz önüne alındığında sadece "...bakılır" ifadesine kesin yetki kuralı manasının verilmemesi gerekir. Çünkü kesin yetki kuralları konusunda HMK'nun tutumu, kesin yetki kurallarını açıkça belirlemek şeklindedir.

Ikinci olarak kanunun gerekçesinden hareket edilerek bir değerlendirme yapılabilecektir. Doktrinde ileri sürüldüğü üzere HMK Tasarısı'nın 12. maddesinin gerekçesinde ortak yetkili mahkemeye ilişkin söz konusu yetki kuralının hukuki niteliğinin kesin yetki olduğunun belirtilmesi ${ }^{81}$ bu yetki kuralına kesin yetki kuralı niteliği sağlayacak mıdır? Öncelikle kanunların gerekçelerinin kanunların yorumundaki önemi açısından bir değerlendirme yapmak gerekmektedir. Tarihsel yorum yöntemine göre bir kanun hükmünün yorumunda kanun koyucunun amacının değerlendirilmesi için kanunun hazırlık aşamalarındaki komisyon ile mecliste yapılan tartışmalara ve kanunun gerekçesine bakmak gerekmektedir ${ }^{82}$. Kanunun yorumunda bu şekilde kanun koyucunun esas amacının araştırılmasına sübjektif yöntem de denilmektedir. Bu yöntem, toplumsal yaşamın, insan haklarının ve hukukun dinamikliği karşısında doğru sonuçlara ulaştıramayacak bir yorum türüdür. Bir kanun çalışması, kanunlaştığı andan itibaren geçmişinden koparak bağımsızlık kazandığından ve gerekçenin artık o madde metninin bağlayıcı kısmına dâhil olmadığından bu yöntem eleştirilmektedir ${ }^{83}$. Kanun; aşamalarının başlangıcında oluşturulan gerekçesinin de oylanmasıyla değil, kanun koyucunun maddenin esas metnine yönelik bir iradesi ile kanunlaştığı da unutulmamaIıdır. Bu çerçevede gerekçede belirtilen hukuki nitelendirmelerin kanun koyucunun esas iradesinin ürünü olan madde metninde yer almaması hususu dikkate alınarak ve HMK'nun sistematiğinde kesin yetki hallerinin açıkça belirtilmesini de göz önüne alarak söz konusu düzenlemenin kesin yetki kuralı olduğu yönündeki görüşlere katılmamaktayız.

\footnotetext{
80 AKKAN, Pekcanitez Usul, s. 277; YILMAZ E. , s. 328.

81 AKKAN, Pekcanitez Usul, s. 274-278; YILMAZ E. , s. 325.

82 GÖZLER, s. 267; GÜRiZ, s. 66-67; EDis, s. 190-191.

83 GÖZLER, s. 269; GÜRiZ, s. 67; EDis, s. 191.
} 
Üçüncü olarak doktrinde ileri sürülen davalılardan biri hakkında açılan davanın hukuki sebebinin farkılışması bu yetki kuralının uygulanmasına engel teşkil edeceği görüşüne ${ }^{84}$ de katılmamaktayız. Bize göre, dava sebebi kavramından anlaşılması gereken davanın temelini teşkil eden vakıalardır ${ }^{85}$. Bu kabulün sonucu da, bir davada ileri sürülen uyuşmazlık esasında haksız fiil teşkil eden vakıaya dayanılıp davalııarın bir kısmına karşı sözleşmesel ilişkiye dayanılabiliyorsa bu durum ortak yetkili mahkeme kuralının uygulanmasına engel teşkil etmemelidir ${ }^{86}$. Nitekim yetkiye ilişkin hususlar usul hukukuna ilişkin hususlar olduğundan vakıaların ve delillerin incelenmesi sonucu ulaşılacak bir sonucun davanın başında karara bağlanması mümkün olarak kabul edilmemelidir.

Dördüncü olarak doktrinde ortak yetkili mahkemenin yetkisinin kesin yetki kuralı olduğu kabul edildikten sonra çoğunlukla haksız fiilden doğan davalarda haksız fiilin meydana geldiği yer mahkemesinin yetkisi örnek gösterilmektedir ${ }^{87}$. Oysaki hakSız fiilden doğan davalar dışında da ortak yetkili mahkemenin söz konusu olabilir88. Somut olayın şartları sağlandığı takdirde "sözleşmenin ifa yeri mahkemesinin yetkisi"89, "şubenin bulunduğu yer mahkemesi", "zarar sigortalarında malın bulunduğu yer mahkemesi" gibi mahkemelerin yetkileri ortak yetkili mahkeme sıfatını alabilecektir ${ }^{90}$. Yargı kararlarında da bu hükmün haksız fiilden doğan davalar bakımından değerlendirilmesi yapılmaktadır. Ancak haksız fiilden doğan davalarda da somut olayın özelliklerine göre yetkili mahkeme sadece haksız fiilin işlendiği yer mahkemesi olmayıp, zararın meydana geldiği yer mahkemesi ya da zararın meydana gelme intimalinin bulduğu yer mahkemesi gibi mahkemeler olabilir ${ }^{91}$. Bir somut olayda zararın meydana geldiği yer, tüm davalılar için, fiilin işlendiği yerden farklı yerde gerçekleşebilir. Bu durumda ortak yetkili mahkeme birden fazla olabilecektir. Dolayısıyla söz konusu durum kesin yetkinin tek mahkeme olabileceği kabulümüzle bağdaşmayacaktır ve ortak yetkili mahkemeye ilişkin yetki kuralının kesin yetki kuralı olduğu bu gerekçeyle de ileri

\footnotetext{
84 YILMAZ E. , s. 322.

85 TANRIVER, Usul, s. 492-499; SOYLU, s. 470-471.

86 SOYLU, s. 473.

87 Haksız fiilden doğan davalarda ortak yetkili mahkemenin sadece haksız fiilin işlendiği yer mahkemesidir görüşüne ilişkin bkz. (GÖRGÜN, s. 96).

88 SOYLU, s. 462.

89 KIYAK, s. 94; SÜRAL, s. 171; "'Sözleşmenin ifa edileceği yer mahkemesi' vakıadan ziyade hukuki ilişki esaslı bir yetki kuralı olduğundan dava sebebine göre düzenlenmiş yetki kuralları 'HMK'nun 15. maddesi' ve 'HMK'nun 16. maddesi'ndeki yetki kurallarıdır." (SOYLU, s. 475476).

$90 \quad$ KIYAK, s. 94.

91 SÜRAL, s. 185; ARSLAN/YILMAZ/TAŞPINAR AYVAZ/HANAĞASI, s. 210; YILMAZ E. , s. 462.
} 
sürülemeyecektir. Bunlara ilaveten haksız fiilden doğan davalar bakımından ortak yetkili mahkemenin kesin yetkili mahkeme olduğu kabul edilirse bütün ihtiyari dava arkadaşlığı durumlarında HMK'nun 7. maddesinin birinci fıkrasının birinci cümlesindeki kural uygulanamaz hale gelecektir. Bu da kanunun amacıyla bağdaşmaz ${ }^{92}$.

Beşinci olarak yargı kararlarında önceki kanun döneminde iş mahkemelerinin yetkisinin kamu düzeninden olduğu gerekçesiyle uygulanmayan ortak yetkili mahkeme kuralının günümüzde de uygulanamayacak bir hale geldiği ifade edilebilir. Çünkü 7036 sayılı Kanun'un 6. maddesinde yetkili mahkemeler birden fazla düzenlendiğinden kanun koyucunun bu davalar bakımından kesin yetki kuralı öngörmek istemediği savunulabilecektir.

Altıncı olarak haksız fiilden doğan davalarda yetkinin düzenlendiği HMK'nun 16. maddesinde seçimlik yetki kurallarına yer verilmiş ve hukuki nitelik itibariyle de kesin olmayan yetki kuralı düzenlenmiştir. Haksız fiilden doğan davalarda yetkinin bu şekilde düzenlenmesinin amacı; haksız fiilin işlendiği veya zararın meydana geldiği yer mahkemesine delillerin toplanmasında ve takdir edilmesinde kolaylık sağlamaktır. Zarar görenin yerleşim yeri mahkemesinin yetkisinin kabul edilmesindeki amaç ise hak aramanın kolaylaştııılmasıdır ${ }^{93}$. Zararın meydana gelme ihtimalinin bulunduğu yer mahkemesinin yetkisi kabul edilerek zararın önlenmesine yönelik açılacak davalarda davacıya kolaylık sağlamak amaçlanmaktadır ${ }^{94}$. Haksız fiilden doğan davalar bakımından düzenlenen yetki kuralları, tarafların üzerinde serbestçe tasarruf edebileceği niteliktedir ${ }^{95}$. Dolayısıyla haksız fiilden doğan davalarda öngörülen yetki kurallarının birinin diğerinden üstün olmaması nedeniyle ortak yetkili mahkeme düzenlemesi haksız fiilden doğan davalara yönelik bir kesin yetki kuralı getirmemektedir.

Ortak yetkili mahkeme kuralının hukuki niteliğinin kesin olmayan yetki kuralı olduğunu düşünmekteyiz. Doktrinde bu yetki kuralının kesin olmayan ancak kesin yetki kuralına yaklaşan bir kural olduğu ifade edilmiş ${ }^{96}$ ise de bu şekildeki bir yaklaşım kanaatimizce isabetli değildir. Ortak yetkili mahkeme kuralının uygulanabileceği bir uyuşmazlıkta seçimlik diğer yetki kuralları da uygulanabilir haldedir. Bu sonuç, ortak

\footnotetext{
92 ALANGOYA/YILDIRIM/DEREN YILDIRIM, s. 91.

93 KARSLI, S. 272.

$94 \mathrm{HASIRCI}$, s. 94-95; KARSLI, s. 272.

95 GÖRGÜN, s. 96; kamu düzeni kavramı özellikle HUMK döneminde geçerli olan kurallar açısından önemli bir kavramdı. Ancak HMK açısından burada kamu düzeni kavramından çok tarafların üzerinde serbestçe tasarruf edebileceği dava kavramı öne çıkmaktadır. Taraflar haksız fiile ilişkin davalarda, dava konusu üzerinde serbestçe tasarruf edebileceklerdir.
} 
yetkili mahkeme kuralının kesin olmayan yetki kuralı niteliği taşımasından kaynaklanır. Dolayısıyla doktrinde ileri sürülen görüşe göre ortak yetkili mahkeme kuralını kesin yetkiye yaklaşan bir yetki kuralı olarak nitelendirmenin hukuki bir sonucu bulunmamaktadır. Kesin yetkiye yaklaşan bir yetki kuralı olarak nitelendirilmesi gerektiğini savunan görüş davalılardan birinin yerleşim yerinde davanın açılması durumunda davanın ortak yetkili mahkemede açılacağı yönünde yapılan yetki ilk itirazını mahkemenin kabul etmesi gerektiğini belirtmektedir ${ }^{97}$. Kanımızca haksız fiilden doğan ve davaıların birden fazla olması durumunda açılan bir dava, davalılardan birinin yerleşim yerinde açıldığı takdirde davalılardan diğerinin ortak yetkili mahkemede davanın açıması gerektiğini belirterek yetki ilk itirazında bulunup yetkisizlik kararı alması mümkün değildir. Bu yetki ilk itirazının reddedilmesinin gerekçesini davanın yetkili mahkemelerden birinde açılmış olması oluşturmaktadır. Seçimlik yetki kurallarının olduğu bir uyuşmazlıkta bu seçimlik yetki kurallarından birinin kullanılması halinde buna yönelik yetki ilk itirazında bulunulması mümkün değildir. Bu durum kesin olmayan yetki kurallarının hukuki niteliğinin bir gereği olarak karşımıza çıkmaktadır.

Haksız fiillerden doğan davalara yönelik yetki sözleşmesi yapılabilmesi kanaatimizce mümkündür ${ }^{98}$. Bu noktada ilk akla gelen HMK'nun "uyuşmazlığın kaynaklandığı hukuki ilişkinin belirli veya belirlenebilir olması" ifadesinden dolayı haksız filin hukuki ilişki olup olmadığı sorusudur. HUMK'nun 22. maddesinde yetki sözleşmesine ilişkin söz konusu geçerlilik şartı " ...muayyen hususa müteallik ihtilaflarının..." şeklinde ifade edilmekteydi. HMK'nda hukuki ilişki tabirinin kullanılması önceki düzenlemeden daha dar tercih yapıldığı yönünde yorumlanmamalıdır ${ }^{99}$. HMK'nun 18. maddesindeki bu geçerlilik şartı kanaatimizce tarafların sadece aralarında sözleşmesel bir ilişkinin bulunduğu hususlardan ziyade geniş bir hukuki ilişki ${ }^{100}$ sahasını ifade etmektedir. Haksı fiilin gerçekleşmesiyle birlikte hakkı ihlal edilen ile hakkı ihlal eden arasında bir hukuki ilişki meydana gelmektedir. Bu hukuki ilişki, haksız fiilden doğan sorumluluktur. Haksız fiilden doğan davalar bakımından hukuki bağın tesisi sağlandığı andan itibaren yetki sözleşmesi yapılabilmesi mümkündür. Yetki sözleşmesinin yapılabileceği en müsait örneklerden bir tanesi trafik kazaları sonucunda tarafların olayı tutanağa bağlamaları esnasında tutanağa yetki şartı eklemeleridir. Bu durumun gerçekleşmesi için tarafların aralarında sözleşmesel bir ilişki olması gerekmemektedir. Yetki sözleşmesi yapılabilmesi için HMK'nun 17. maddesine göre taraflar arasında da

\footnotetext{
97 KARADEMIR AYDEMIR, s. 180.

98 BELGIN GÜNEŞ, s. 208; BOLAYIR, Yetki Sözleşmeleri, s. 142; BOLAYIR, Yeni HMK, s. 141.

99 BUDAK, Yetki Sözleşmesi, s. 2.

100 Hukuki ilişki; hakkın sahibi ile yükümlü arasında bulunan hukuki bağdır (EREN, s. 27; OĞUZMAN/ÖZ, s. 3; TEKINAY/AKMAN/BURCUOĞLU/ALTOP, s. 5).
} 
herhangi bir ticari iş ya da ticari davaya vücut verebilecek bir ilişki bulunması şartı kanunun lafzından anlaşılmamaktadır ${ }^{101}$. Kanunun aradığı geçerlilik şartları gerçekleştirildiği takdirde haksız fiilden doğan davalarda yetki sözleşmesi söz konusu olabilecektir. Dolayısıyla haksız fiilden doğan davalarda davalıların birden fazla olması halinde söz konusu yetki kuralının kesin olmayan yetki niteliği kabul edilirse yetki sözleşmesi söz konusu olabilecektir.

Son olarak kanunda kesin olduğu belirtilmeyen bir yetki kuralının yorum yolu ile kesin yetki kuralı haline getirilmesi durumunda, davacının diğer yetkili mahkemelerde dava açma imkânı elinden alınmaktadır. Bu durumun ise hak arama hürriyetini sınırlandırdığı düşünülebilir. Çünkü davacının o uyuşmazlık için gösterilen yetkili mahkemelerde dava açabilme imkânı yorum yoluyla sınırlandırılmaktadır. Davacıya, yorum yolu ile sadece haksız fiilin işlendiği yer mahkemesinde dava açma imkânı verilmektedir. Oysaki kanun koyucu haksız fiillerde, davacıya hak aramayı kolaylaştırmak için birden fazla yer mahkemesinde dava açma imkânı vermiştir. Bu sayede davacı davasını rahatlıkla açma imkânına sahiptir. İşte bu imkânın yorum yolu ile sınırlandırılamaması gerekir. Ortak yetkili mahkeme kesin yetkili mahkeme olarak anlaşılmamalıdır ve taraflar haksız fiilden doğan davalarda geçerlilik şartlarını sağlayarak yetki sözleşmesi de yapabilmelilerdir.

\section{SONUÇ}

HMK'nun 7. maddesinin birinci fıkrasının ikinci cümlesinde ifade edilen yetki kuralı esasen kesin yetki kuralı değildir. Bu maddenin lafzında "kesin yetkili" ifadesine yer verilmemesinden anlaşılmaktadır. Ortak yetkili mahkeme somut olayın özelliklerine göre birden fazla mahkemeyi ifade edebilecektir. Dolayısıyla kanaatimizce söz konusu yetki kuralının kesin olduğunun ileri sürülmesi kesin yetki kavramıyla bağdaşmayacaktır.

Ortak yetkili mahkemenin söz konusu olması durumunda seçimlik yetkinin kalkması durumu kabul edilmemelidir. Çünkü söz konusu yetki kurallarının amacı bağlamında bir değerlendirme yapılacak olsa her yetki kuralının amacı bir diğerine üstün tutulamayacak niteliktedir. İstisnai olarak amacın üstün tutulacağı durumlarda kanun koyucu kesin yetkiyi açıkça kendi iradesiyle belirtmiştir. Mahkemelerin yetkisine ilişkin durumların yorum yoluyla sınırlandırılması bu noktada kabul edilememelidir.

Haksız fiilden doğan davalarda haksı fiilin işlendiği yer ortak ve kesin yetkili mahkeme olarak kabul edilmemelidir. Netice olarak haksız fiilden doğan davalarda

101 Doktrinde bir görüş yetki sözleşmesinin ticari olmayan uyuşmazlıklarda yapılabileceğini ileri sürmektedir AŞIK, s. 25; diğer bir görüşe göre ise yetki sözleşmesi kanunun amacı gereği ticari işle sınırlı olarak yapılabilecektir BELGIN GÜNEŞ, s. 203; TOPUZ, s. 105. 
yetkinin düzenlendiği HMK'nun 16. maddesinde seçimlik yetki kuralı olarak ve hukuki nitelik itibariyle de kesin olmayan yetki kuralı düzenlenmiştir. Kanunda kesin olduğu belirtilmeyen bir yetki kuralının yorum yolu ile kesin yetki kuralı haline getirilmesi durumunda, davacının diğer yetkili mahkemelerde dava açma imkânı elinden alınmakta ve bu durum ise hak arama hürriyetini sınırlandırmaktadır. 


\section{KAYNAKLAR}

AKiL Cenk, 6100 Sayılı Hukuk Muhakemeleri Kanunu'nda Çekişmeli Yargıya Iliş̧in Kesin Yetki Halleri (MiHDER Y. 2012 C. 8 S. 22, s. 107-163).

AKIL Cenk/PEKSÖZ Vildan, Para Alacaklarına İlişkin Illamsız Takipte İcra Dairelerinin Yetkisi, (Uluslararası Antalya Üniversitesi Hukuk Fakültesi Dergisi Y. 2016 S.8, s. 25-40).

AKKAN Mine, Medeni Usul Hukukunda Etkin Hukuki Koruma, (MiHDER Y. 2007 C. 3 S.6, s. 29-68). (Etkin Hukuki Koruma).

AKKAN Mine, Pekcanıtez Usul - Medeni Usul Hukuku, C. I, 15. B., İstanbul 2017. (Pekcanitez Usul).

AKKAYA Tolga, Medeni Usul Hukuku Bakımından Boşanma Davası, Ankara 2017.

ALANGOYA H. Yavuz/ YILDIRIM M. Kamil/ DEREN YILDIRIM Nevhis, Medeni Usul Hukuku Esasları, 8. B., İstanbul 2011.

ARSLAN Ramazan/TANRIVER Süha, Yargı Örgütü Ders Kitabı, 2. B., Ankara 2001.

ARSLAN Ramazan/ YILMAZ Ejder/ TAŞPINAR AYVAZ Sema/ HANAĞASI Emel, Medeni Usul Hukuku, 4. B., Ankara 2018.

AŞIK Ibrahim, Hukuk Muhakemeleri Kanunu'na Göre Yetki Sözleşmesi, (Türkiye Barolar Birliği Dergisi Y. 2011 S. 97, s. 11-48).

ATALI Murat/ ERMENEK İbrahim/ ERDOĞAN Ersin, Medeni Usul Hukuku, Ankara 2018.

BELGIN GÜNEŞ Derya, Yetki Sözleşmeleri, (İstanbul Barosu Dergisi Y. 2012 C. 86 S. 5, s. 197-221).

BERKiN Necmeddin M., Medeni Usul Hukuku Esasları, İstanbul 1969.

BiLGE Necip/ ÖNEN Ergun, Medeni Yargılama Hukuku Dersleri, Ankara 1978.

BOLAYIR Nur, Medenî Usûl Hukukunda Yetki Sözleşmesi, İstanbul 2009. (Yetki Sözleşmeleri).

BOLAYIR Nur, Yeni HMK'ya Göre Yetki Sözleşmeleri, (İstanbul Barosu Dergisi Y. 2011 C. 85 S. 5, s. 131-147). (Yeni HMK).

BUDAK Ali Cem, Hukuk Muhakemeleri Kanunu'na Göre Yetki Sözleşmesi, (MiHDER Y. 2012 C. 8 S. 21, s.1-25). (Yetki Sözleşmesi).

BUDAK Ali Cem, Hukuk Muhakemeleri Kanunu'nun Görev, Yetki ve Yetki Sözleşmesi (HMK m.5-19) Konularında Getirdiği Yenilikler, (Bankacılar Dergisi Y. 2013 C. 24 Özel Sayı, s. 42-61). (Yenilikler).

BUDAK Ali Cem/ KARAASLAN Varol, Medeni Usul Hukuku, 2. B., Ankara 2018. 
DAYINLARLI Kemal, Milli ve Milletlerarası Kamu Düzeni Tahkime Etkileri ve Sonuçları, 2. B., Ankara 2011.

EDis Seyfullah, Medeni Hukuka Giriş ve Başlangıç Hükümleri, 4. Basıdan Tıpkı B., Ankara 1993.

EREN Fikret, Borçlar Hukuku Genel Hükümler, 23. B., Ankara 2018.

GIRITLi İsmet/ BILGEN Pertev/ AKGÜNER Tayfun/ BERK Kahraman, İdare Hukuku, 7. B., İstanbul 2015.

GÖRGÜN L. Şanal, Medeni Usul Hukuku, 4. B., Ankara 2015.

GÖZLER Kemal, Hukuka Giriş, 12. B., Bursa 2015.

GÜRiZ Adnan, Hukuk Başlangıcı, 13. B., Ankara 2011.

HASIRCI Hakan, Medeni Usul Hukuku Bağlamında Tabi Hakim IIlkesi, (Yayınlanmamış Yükseklisans Tezi), Ankara 2013.

KARADEMiR AYDEMiR Dilek, Medeni Usul Hukukunda Mahkemelerin Yetkisi, 2. B., Ankara 2019.

KARSLI Abdurrahim, Medeni Muhakeme Hukuku, 3. B., İstanbul 2012.

KILIÇOĞLU Mustafa, 6100 Sayılı Hukuk Muhakemeleri Kanunu El Şerhi, İstanbul 2012.

KIYAK Emre, Türk Hukukunda Dava Sebebine Göre Davalıların Tamamı Hakkında Ortak Yetkiyi Taşıyan Mahkemenin Yetkisi Üzerine Düşünceler, (Terazi Hukuk Dergisi Y. 2017 C. 12 S. 127, s. 92-99).

KOCAYUSUFPAŞAOĞLU Necip/ HATEMi Hüseyin/ SEROZAN Rona/ ARPACI Abdulkadir, Borçlar Hukuku Genel Bölüm, C. I., 7. B., İstanbul 2017.

KONURALP Orhan Emre, Hukuk Muhakemeleri Kanunu'na Göre Ortak Yetkili Mahkeme Ile Münhasır Yetki Sözleşmesiyle Belirlenen Mahkemenin Yetkisinin Niteliği, (Türkiye Barolar Birliği Dergisi Y. 2019 S. 142, s. 211-230).

KURU Baki, Hukuk Muhakemeleri Usulü, C. I, 6. B., İstanbul 2001. (Muhakeme).

KURU Baki, İstinaf Sistemine Göre Yazılmış Medeni Usul Hukuku, İstanbul 2016. (Usul).

OĞUZMAN M. Kemal/ ÖZ, M. Turgut, Borçlar Hukuku Genel Hükümler, C. I., 16. B., İstanbul 2018.

POSTACIOĞLU IIlhan E., Medeni Usul Hukuku Dersleri İstanbul 1975.

POSTACIOĞLU illhan E./ ALTAY Sümer, Medeni Usul Hukuku Dersleri, 7. B., İstanbul 2015. 
SOYLU M. Furkan, Medeni Usul Hukukunda Ortak Yetkili Mahkeme, (Selçuk Üniversitesi Hukuk Fakültesi Dergisi Y. 2017 C. 25 S. 2, s. 449-484).

SÜRAL, B. Ceyda, Hukuk Muhakemeleri Kanunu'nun Türk Mahkemelerinin Milletlerarası Yetkisine Etkisi, (Türkiye Barolar Birliği Dergisi Y. 2012 S. 100, s. 167216).

TANRIVER Süha, Yabancı Hakem Kararlarının Türkiye'de Tenfizi Bağlamında Kamu Düzeninin Etkisi, (Milletlerarası Hukuk ve Milletlerarası Özel Hukuk Bülteni Y. 1997 C. 17 S. 1-2, s. 467-492). (Kamu Düzeni).

TANRIVER Süha, Medeni Usul Hukuku, 2. B., Ankara 2018. (Usul).

TAŞ KORKMAZ Hülya, 6100 Sayılı Hukuk Muhakemeleri Kanunu'nun Görev, Yetki ve Yargı Yeri Belirlenmesine İlişkin Hükümlerinin Değerlendirilmesi, (Prof. Dr. Aydın Zevkliler'e Armağan, Yaşar Üniversitesi Elektronik Dergisi Y. 2013 C. 8 Özel Sayı, s. 1753-1818).

TEKINAY Selahattin Sulhi/ AKMAN Sermet/ BURCUOĞLU Haluk/ ALTOP Atilla, Tekinay Borçlar Hukuku Genel Hükümler, 7. B., İstanbul 1993.

TOPUZ Gökçen, Tüketici Mahkemeleri. Ankara 2018.

TUTUMLU M. Akif, Ortak Yetkili Mahkeme Hükmünün Kesin Yetki Niteliğinde Olup Olmadığı Sorunu, (Terazi Hukuk Dergisi Y. 2017 C. 12 S. 136, s. 98-103).

ULUKAPI Ömer, Medeni Usul Hukuku, 2. B., Konya 2014.

UMAR Bilge, Hukuk Muhakemeleri Kanunu Şerhi, 2. B., Ankara 2014.

ÜSTÜNDAĞ Saim, Medeni Yargılama Hukuku, C. I-II., 7. B., İstanbul 2000.

YILMAZ Ejder, Hukuk Muhakemeleri Kanunu Şerhi, C. I., Ankara 2017.

YILMAZ Mehmet, Mahkemelerin Kamu Düzenine Ilişkin Yetkisi, Ankara 2007. 